\title{
Review on Plants for Management of Diabetes in India: An Ethno- Botanical and Pharmacological Perspective
}

\author{
Shikha Dixit*, Sugandha Tiwari
}

\section{Shikha Dixit*, Sugandha Tiwari \\ Department of Botany, DGPG College, CSJMU Kanpur, INDIA. \\ Correspondence \\ Shikha Dixit \\ Department of Botany, DGPG College, CSJMU Kanpur, INDIA. \\ Phone no: 6306845929 \\ E-mail: dixitshikha0730@gmail.com \\ History \\ - Submission Date: 21-06-2020; \\ - Review completed: 23-07-2020; \\ - Accepted Date: 08-08-2020.}

DOI : 10.5530/pj.2020.12.243

\section{Article Available online}

http://www.phcogj.com/v12/i6s

Copyright

(C) 2020 Phcogj.Com. This is an openaccess article distributed under the terms of the Creative Commons Attribution 4.0 International license.

\section{ABSTRACT}

Background: Diabetes mellitus is a prevalent chronic disease, which is recognized as a common threat to health in the last decade, especially in Asia. It is a lifestyle disease which may cause a number of complications in the body of humans like cardiac failure and dysfunctioning of urinary tract. Materials and Methods: The data is obtained from various search tools and electronic databases like, scientific literature, Google scholar, Google, Pubmed, Web of science and Scopus. Results: Major therapy for diabetes is insulin, oralantidiabetic drugs, and herbal treatment. However, insulin and oral anti-diabetic drugs come with a number of side effects and cannot be afforded by people with below poverty line. The herbal medicines have performed a satisfactory clinical practice for the management of diabetes mellitus. Moreover, pharmacological \& phytochemical screening of medicinal plants has also witnessed the hypoglycaemic effects of these plants in treating diabetes mellitus. Majority of the modern drugs like metformin, atropine, digitalis, etc. are also originated from plants. Conclusion: The current paper presents a review of medicinal plants used for diabetes management in India. The therapeutic potential, ethnobotanical use, and their pharmacological evaluations are highlighted for harnessing the anti-diabetic potential of these plants by the Indian healthcare system.

Key words: Diabetes management, India, Ethnopharmacology, Herbal drugs.

\section{INTRODUCTION}

Diabetes mellitus is one of the major challenges across the globe, resulting in great financial and medical burden to the patients ${ }^{1}$. As per WHO, the worldwide prevalence of diabetes was recorded as $8.8 \%$ in 2017 whereas, 1.6 million deaths occurred owing to diabetes in $2016^{2,3}$. According to International Diabetes Federation (IDF), the diabetic population of the globe will reach to 629 million by 2045 , which was recorded as 425 million in $2017^{4}$. Moreover, Nagarathna et al. ${ }^{5}$ stated that the diabetic population of India is projected to reach 79.4 million by 2030 . Chen et al. ${ }^{6}$ reported continent wise prevalence of DM which is depicted in Figure 1. The Indian subcontinent has risen as the capital of this epidemic disease. Here, the estimated prevalence of diabetes in age group 20-79 of Bangladesh is $9.85 \%$, India $8.31 \%$, Sri lanka $7.77 \%$, Pakistan $6.72 \%$, whereas it is recorded as $3.03 \%$ for the nepal ${ }^{7}$. The age-related prevalence of diabetes in India is higher in comparison to some other populations ${ }^{8}$. The Indians posses increased insulin level at a given BMI, which signalizes peripheral insulin resistance due to higher body fat percentage 9. The prime factors for contributing increased level of type II diabetes and hyperinsulinemia in Indians are low muscle mass, typical abdominal deposition pattern, racial predisposition and excessive body fat ${ }^{10}$.

Generally, diabetes occurs in various forms but type I, type II and gestational are the dominating ones ${ }^{11}$. Type I diabetes occurs when beta cells does not produces sufficient amount of insulin. It is detected more in children whereas, type II occurs when insulin receptors are unable to use the produced insulin. However, type II is more common form which is found in the majority of the patients. It occurs due to lack of disciplined lifestyle like lack of physical activity, unhealthy diet, stress, obesity. Gestational diabetes occurs during pregnancy ${ }^{12}$. The vital cause for diabetes is metabolic dysregulation of carbohydrate, which leads to impaired insulin action, defect in insulin secretion or both ${ }^{13}$. Polydipsia, frequent urination, headaches, weight loss, high level of sugar in urine, fatigue are some of the common symptoms of diabetes ${ }^{14}$. Uncontrolled diabetes management results in number of complications affecting both microvascular and macrovascular. Microvascular complications includes nephropathy (kidney damage), retinopathy (eye damage), neuropathy (nerves damage) and macrovascular includes peripheral vascular disease (poor circulation to the limb), cardiovascular diseases (risk of heart attack), cerebrovascular disease (risk of stroke) ${ }^{15}$.

\section{Diagnosis of Diabetes mellitus}

The diagnosis of early diabetes includes Glycosylated Haemoglobin (HbA1C), Glucose Tolerance Test (GTT), Fasting Plasma Glucose (FPG), Postprandial Plasma Glucose (PPG) test ${ }^{16}$. GTT helps to diagnose gestational diabetes, pre-diabetes, insulin resistance or reactive hypoglycemia. FPG \& PPG level reflect the state of recent glycemia, whereas HbAlc level reflects chronic glycaemia. As per American Diabetes Association (ADA), HbAlc should be less than 7\% 

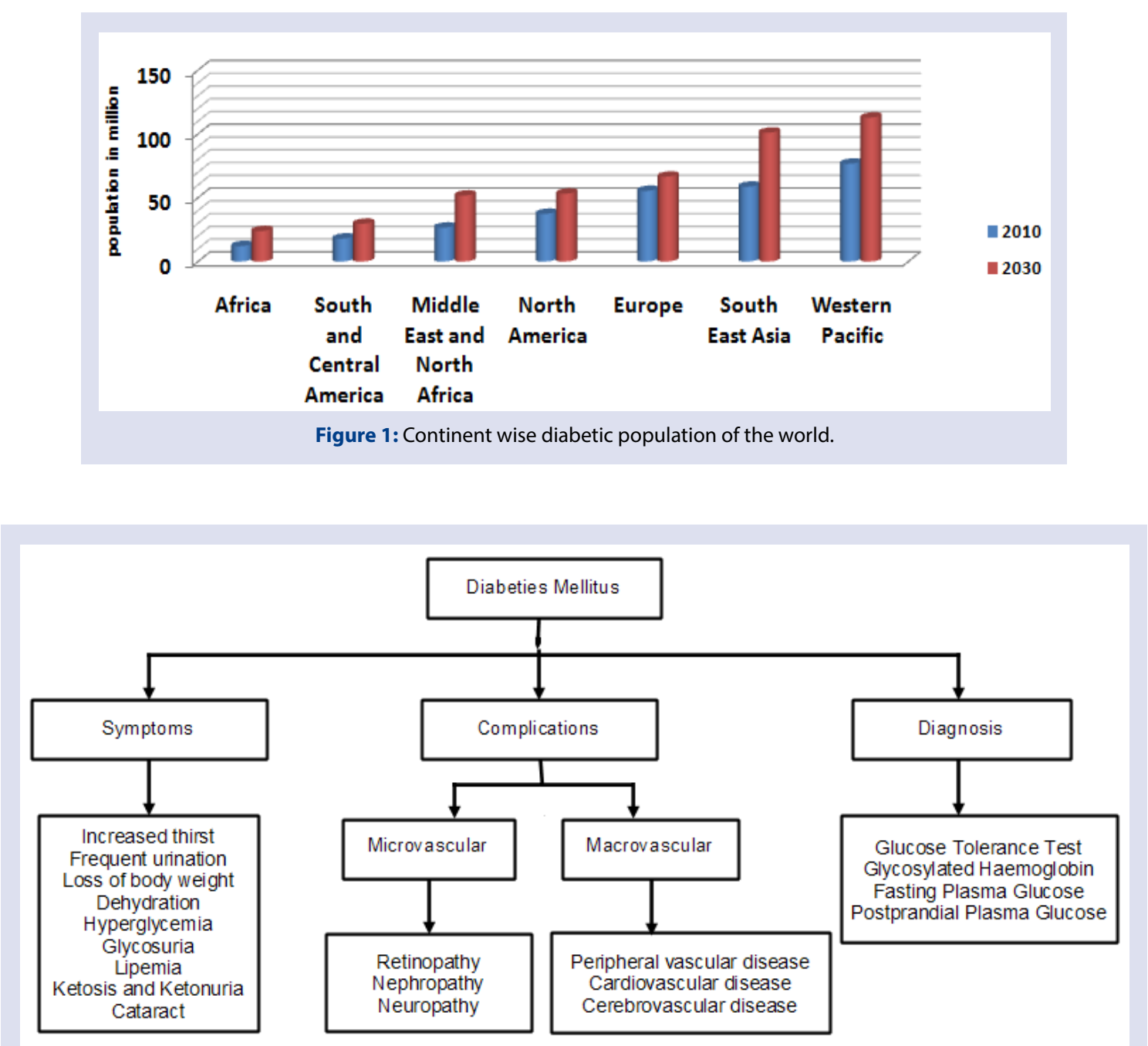

Figure 2: Symptoms, complications and diagnosis of diabetes mellitus.

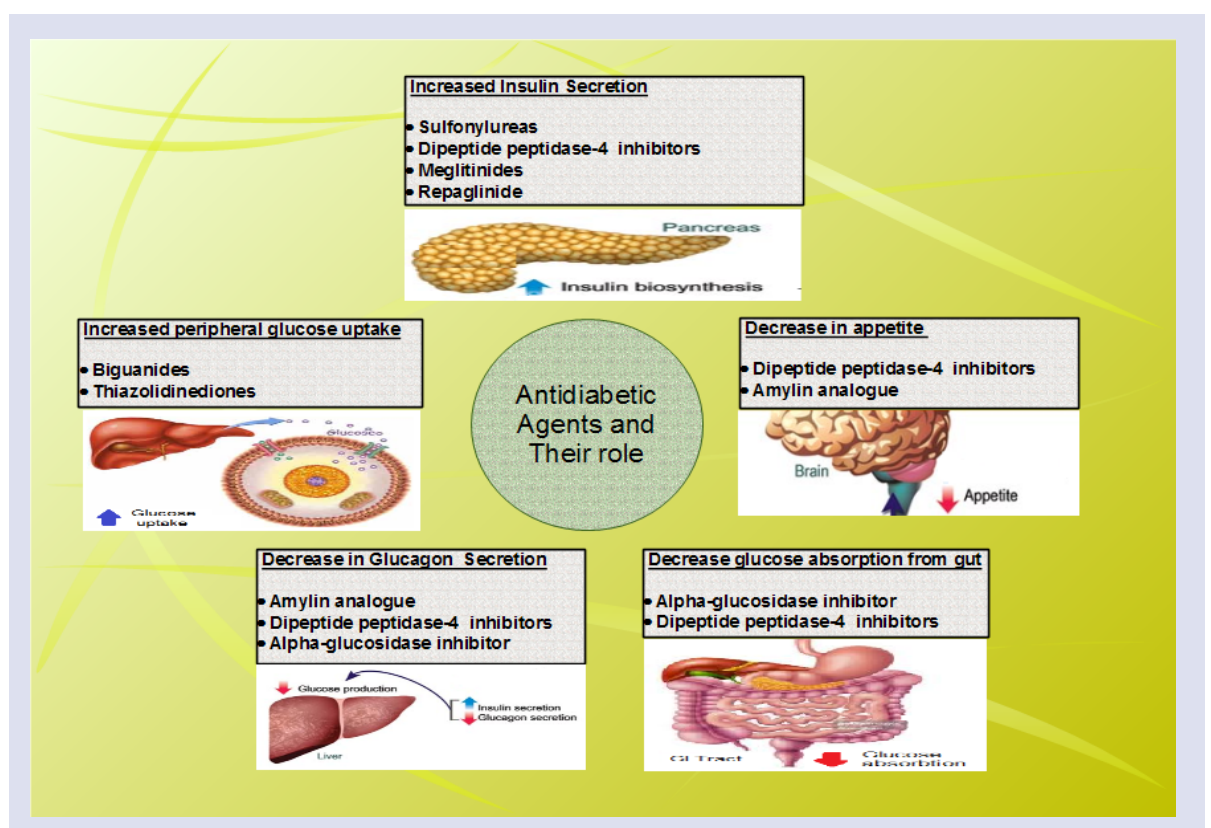

Figure 3: Oral antidiabetic agents and their role in treating diabetes mellitus. 
whereas, fasting plasma glucose (FPG) should be $70-130 \mathrm{mg} / \mathrm{dl}(3.9-$ 7.2) $\mathrm{mmol} / \mathrm{l}$ ) for glycemic control. Moreover, the postprandial glucose (PPG) should be under $180 \mathrm{mg} / \mathrm{dl}(<10 \mathrm{mmol} / \mathrm{l}){ }^{17}$.

\section{Current treatments of Diabetes mellitus}

The major treatments for DM are conventional therapy, complementary therapy and alternative medication as described in Table 1. Conventional therapy includes chemically synthesized oral antidiabetic drugs and insulin whereas, complementary therapy includes yoga and acupuncture. However, herbal medication is based on plant formulations. The various oral anti-diabetic drugs such as Metformin, a-glucosidase inhibitors, Dipeptidyl peptidase-4 (DPP), Biguanides, Sulphonylureas, Meglitinides and Thiazolidinediones are diverse in their mode of action, endurability and safety profiles ${ }^{18}$. The recommended first choice for the treatment of diabetes is metformin however, high glucose level requires administration of insulin ${ }^{19}$. Insulin is also known as principal hormone, as it regulates level of blood glucose. It transfers blood glucose to tissues. The storage of insulin in body takes place in units of 6 molecules and its active form is a monomer. According to UK Prospective diabetes study, the standard treatment for type 1, some forms of type II, and gestational diabetes is insulin and its analogue ${ }^{20}$. In addition, Sulphonylureas and meglitinides stimulates pancreas to increase the release of insulin. Thiazolidinediones reforms insulin activity, whereas $\alpha$-glucosidase inhibitors check digestion and absorption of carbohydrate from the gut. Biguanides acts by promoting glucose utilization and reducing hepatic glucose production, DPP4 inhibits glucagon release and increases insulin secretion ${ }^{21,22}$. Currently, some advanced classes of drugs are also available such as SGLT-2i therapy based on exendin (exenatide once in a week) ${ }^{23}$ and glucagon-like peptide (GLP)-1 analogue (taspoglutide and liraglutide) ${ }^{24}$. Further, Sodium-glucose co-transporters 2 inhibitors (SGLT2i) are an experimental group of synthetic drugs which exerts hypoglycemic effect. In renal proximal tubules it inhibits glucose reuptake, and thus induces glycosuria. Furthermore, SGLT2 inhibition reduces blood pressure, weight and has renal and cardiac benefits in individuals with preserved renal function ${ }^{25}$. Athyros et al. ${ }^{2}$ in his study reported that GLP-1 analogue, SGLT-2i, and metformin as better than other classes of antidiabetic drugs. In addition these also possess some cardiovascular benefits.

\section{Adverse effects of oral antidiabetic drugs}

Now a days, several oral antidiabetic drugs are available which have either adverse effects or sub-optimal effects on different body parts ${ }^{32}$ such as long term use of metformin causes vit B12 deficiency ${ }^{33}$. Also, it increases risk of lactic acidosis in patients who have pulmonary, cardiac or renal insufficiency or have any history of liver disorder ${ }^{34}$. However, sulfonylureas, glizatones and some DPP-4 inhibitors can induce heart failure ${ }^{35}$. Thus, key challenge in the management of DM is the treatment without any adverse effect. Some oral antidiabetic drugs and there effects have been tabulated in Table 2 .

\section{Herbal remedy}

As per WHO, approximately $90 \%$ of the diabetic patients from developing countries primarily rely on the plants and their products for the management of diabetes mellitus ${ }^{41,42}$. Also, there are about 21,000 medicinlal plants species available across the world out of which about 2500 plant species have been reported from India ${ }^{45}$. Among these, 800 plants have have been reported with antidiabetic potential ${ }^{44}$. The medicinal properties of these plants have been established due to numerous bioactive compounds such as minerals, saponins, tannins, alkaloids, terpenoids, phenols, anthraquinones and flavonoids ${ }^{45}$. Furthermore, a wide collection of data \& documentation of traditional system of medicine helped in scientific investigation on drug development. Although, there is no drug which can cure diabetes completely but green medicines are safe as compared to synthetic drugs ${ }^{46}$. Furthermore, some common and potent medicinal plants with antidiabetic activity having Indian origin are bael (Aegle marmelos), garlic (Allium sativum), neem (Azadirachta indica), beet (Beta vulgaris), mustard (Brassica juncea), sadabahar (Catharanthus roseus), ivy guard (Coccinia indica), banyan tree (Ficus benghalenesis), gurmar (Gymnema sylvestre), gurhal (Hibiscus rosa-sinesis), jamun (Syzygium cumini), mango (Mangifera indica), karela (Momordica charantia), giloy (Tinospora cordifolia), kari patta (Murraya koeningii), tulsi (Ocimum sanctum), pomegranate (Punica granatum), methi (Trigonella foenumgraecum) ${ }^{7}$. Due to natural origin \& less side effects, use of these traditional plants is increasing day by day in developed \& developing countries. Although, botanicals play a crucial role in the treatment of diabetes, however, it requires more exploration for drug development from natural resources. The current review article has an objective to collect various ethno-botanical data of the medicinal plants having hypoglycemic activity and to provide present scientific information of these plants. Some of the commonly used antidiabetic plants and their preparation in various ethnobotanical studies of India are presented in Table 3.

\section{Pharmacological activities of some anti-diabetic plants}

\section{Acacia catechu (L.f.) Wild.}

Bhatia et al. ${ }^{55}$ reported that oral administration of ethanolic extract of A. catechu hard wood at $250 \mathrm{mg} / \mathrm{kg}$ elicits significant antihyperglycemic

Table 1: Current therapies for treatments of Diabetes mellitus.

\begin{tabular}{|c|c|c|c|}
\hline Antidiabetic Medication & Route of administration & Therapy & Ref. \\
\hline Insulin & Oral/Injectable & $\begin{array}{l}\text { Insulin therapy is benefitcial for long term glucose control as monotherapy as well as } \\
\text { in conjunction with other oral antidiabetic medication }\end{array}$ & 21 \\
\hline Orthodox Anti-diabetic drugs & Oral & $\begin{array}{l}\text { Oral antidiabetics like } \alpha \text {-glucosidase inhibitors, DPP- } 4 \text { inhibitors, Biguanides, } \\
\text { Sulphonylureas, Meglitinides and Thiazolidinediones lowers blood glucose level } \\
\text { through different mechanism. }\end{array}$ & 26 \\
\hline SGLT-2 inhibitors & Oral & $\begin{array}{l}\text { It is an experimental group of drugs that helps kidney to decrease the blood glucose } \\
\text { level. It possess minimal adverse effects and few beneficial side effects such as it } \\
\text { decreases dehydration, polyuria, weight loss and hypertension. }{ }^{5}\end{array}$ & 27 \\
\hline GLP-1 analogue & Injectable & $\begin{array}{l}\text { It is a synthetic and incretin based therapy which regulate sugar by stimulating insulin } \\
\text { secretion and inhibiting glucagon secretion. }\end{array}$ & $\begin{array}{l}28 \\
29\end{array}$ \\
\hline Yoga & - & $\begin{array}{l}\text { Bhastrika Pranayama, Surya namaskar, Padmasana, Bhujangasana, Trikonasana, } \\
\text { Shavasana, Sukhasana, Pawanmuktasana, Dhanurasana, Pashimottanasana, and } \\
\text { Ardhmatsyendrasana are helpful in controlling Diabetes mellitus. Yoga lowers down } \\
\text { both fasting blood sugar (FBS) and postprandial blood sugar (PPBS) }\end{array}$ & 30 \\
\hline Herbal drugs & Oral & $\begin{array}{l}\text { They act like insulin or act on insulin secreting } \beta \text {-cells or act by modifying glucose } \\
\text { utilization or by some other mechanism. }\end{array}$ & 31 \\
\hline
\end{tabular}


Table 2: Adverse effects of allopathic dugs for Diabetes mellitus.

\begin{tabular}{|c|c|c|c|}
\hline Antidiabetic Agent & Name of Drug & Adverse Effect & Reference \\
\hline Insulin & $\begin{array}{l}\text { Regular insulin } \\
\text { Isophane insulin }\end{array}$ & Weight gain, hypoglycaemia & 23,36 \\
\hline a-glucosidase inhibitors & $\begin{array}{l}\text { Acarbose } \\
\text { Miglitol }\end{array}$ & Diarrhoea, bloating or flatulence & 23,37 \\
\hline Biguanides & $\begin{array}{l}\text { Metformin } \\
\text { Phenformin }\end{array}$ & Dyspepsia and lactic acidosis & 16,38 \\
\hline $\begin{array}{l}\text { Dipeptidyl peptidase- } 4 \\
\quad(\mathrm{DPP}-4)\end{array}$ & $\begin{array}{l}\text { Sitagliptin } \\
\text { Saxagliptin }\end{array}$ & Suppressor of neoplasm, increased risk of tumors and cancers & 23,38 \\
\hline Sulphonylureas & $\begin{array}{c}\text { Tolbutamide } \\
\text { Chlorproamide } \\
\text { Glipizide } \\
\text { Glimepiride }\end{array}$ & Weight gain \&hypoglycaemia & 23,36 \\
\hline Thiazolidinediones & $\begin{array}{l}\text { Rosiglitazone } \\
\text { Pioglitazone }\end{array}$ & Liver and heart diseases & 16,37 \\
\hline Meglitinides & $\begin{array}{l}\text { Repaglinide } \\
\text { Nateglinide }\end{array}$ & Weight gain \& hypoglycaemic & 23,36 \\
\hline SGLT-2i & $\begin{array}{l}\text { Empagliflozin } \\
\text { Dapagliflozin }\end{array}$ & $\begin{array}{c}\text { Polyuria, hypotension, genital infections, dehydration, and risk } \\
\text { of fracture and amputation }\end{array}$ & 25,39 \\
\hline GLP-1 analogue & $\begin{array}{l}\text { Exenatide } \\
\text { Liraglutide }\end{array}$ & Nausea, vomiting, diarrhea, pancreatitis and thyroid cancer. & 40 \\
\hline
\end{tabular}

Table 3: Some Indian Medicinal Plants with Potential Anti-diabetic Activity.,47-54

\begin{tabular}{|c|c|c|c|c|c|c|}
\hline S. N. & Botanical Name & Common Name & Family & Habit & Part Used & Ethanobotanical Use \\
\hline 1. & Acacia catechu (L.f.) Wild. & Babool & Leguminosae & Tree & Bark & Decoction of bark \\
\hline 2. & Aegle marmelos (L.) Correa & Bael & Rutaceae & Tree & Leaf & Extract of leaf \\
\hline 3. & $\begin{array}{l}\text { Adhatoda vasica } \\
\text { Nees }\end{array}$ & Malabar nut & Acanthaceae & Shrub & $\begin{array}{l}\text { Root, } \\
\text { Leaf }\end{array}$ & Decoction of root and leaf \\
\hline 4. & Allium sativum L. & Garlic & Amaryllidaceae & Herb & $\begin{array}{l}\text { Leaf, } \\
\text { Bulb }\end{array}$ & Leaf and bulb consumed raw \\
\hline 5. & Aloe vera (L.) Burm.f. & Aloe & Liliaceae & Herb & Leaf & Gel eaten raw \\
\hline 6. & Antidesma diandrum Retz. & & Euphorbiaceae & Shrub & Leaf & Boiled extract \\
\hline 7. & $\begin{array}{l}\text { Ananas comosus } \\
\text { (L.) Merr. }\end{array}$ & Ananas & Bromeliaceae & Herb & Whole plant & Leaf decoction and fresh fruit pulp \\
\hline 8. & Argemone Mexicana L. & Poppy & Papaveraceae & Herb & Stem & Curry made from stem \\
\hline 9. & Asparagus racemosus L. & Shatavari & Liliaceae & Climber & Root & Tuberous root juice \\
\hline 10. & Azadiracta indica Juss. & Neem & Meliaceae & Tree & $\begin{array}{l}\text { Leaf, } \\
\text { Seed }\end{array}$ & Leaves antidiabetic \\
\hline 11. & Beta vulgaris L. & Beet & Amaranthaceae & Herb & Root & Root extract \\
\hline 12. & Bombax ceiba L. & Shimul & Bombacaceae & Tree & $\begin{array}{l}\text { Flower, Stem, } \\
\text { Bark }\end{array}$ & Decoction \\
\hline 13. & Brassica juncea (L.) Czern & Mustard & Brassicaceae & Herb & Seed & Seed powder with milk \\
\hline 14. & Cajanus cajan (L.) Millsp. & Pigeon pea & Fabaceae & Shrub & Seed & Cooked seeds taken as food \\
\hline 15. & Cassia tora $\mathrm{L}$. & Tora & Leguminosae & Herb & Seed & Shade dried seed powder \\
\hline 16. & Catharanthus roseus (L.) G. Don & Sadabahar & Apocynaceae & Herb & Flower & 2-3 flowers taken with aloe juice \\
\hline 17. & $\begin{array}{c}\text { Citrullus lanatus (Thunb.) Matsum. \& } \\
\text { Nakai }\end{array}$ & Watermelon & Cucurbitaceae & Vine & Seed & Fruit pulp \\
\hline 18. & Coccinia indica Wight \& Arm. & Ivy gourd & Cucurbitaceae & Climber & Fruit & Used as antidiabetic \\
\hline 19. & Curcuma longa L. & Turmeric & Zingiberaceae & Herb & Rhizome & $\begin{array}{c}8 \mathrm{~g} \text { of grinded turmeric mixed in } \\
\text { water taken with } 1 / 2 \text { teaspoon of } \\
\text { honey after meal }\end{array}$ \\
\hline 20. & Cyperus rotundus L. & Mutha & Cyperaceae & Herb & Rhizome & Fresh juice \\
\hline 21. & Ficus benghalensis L. & Banyan Tree & Moraceae & Tree & $\begin{array}{l}\text { Fruit, } \\
\text { Bark }\end{array}$ & Fruits as antidiabetic \\
\hline 22. & $\begin{array}{c}\text { Gymnema sylvestre (Retz.) R.Br.Ex } \\
\text { Sm. }\end{array}$ & Gurmaar & Apocynaceae & Climber & Leaf & $\begin{array}{l}\text { Leaf powder with jaggery powder } \\
\text { taken orally }\end{array}$ \\
\hline 23. & $\begin{array}{l}\text { Hemidesmus } \\
\text { indicus (L.) R.Br. }\end{array}$ & Anantmool & Apocynaceae & Shrub & Root & Decoction \\
\hline 24. & Hibiscus rosa-sinensis L. & China rose & Malvaceae & Shrub & Leaf & Tender fresh leaf juice \\
\hline
\end{tabular}




\begin{tabular}{|c|c|c|c|c|c|c|}
\hline 25. & Ichnocarpus frutescens (L.) R.Br. & Black creeper & Apocynaceae & Shrub & Root & Powder of root \\
\hline 26. & Lantana camara L. & Wild sage & Verbenaceae & Shrub & $\begin{array}{l}\text { Leaf, } \\
\text { Fruit }\end{array}$ & Consumed raw \\
\hline 27. & Mangifera indica $\mathrm{L}$. & Mango Tree & Anacardiaceae & Tree & Seed & $\begin{array}{l}\text { Dry kernel powder mixed with } \\
\text { cow's milk }\end{array}$ \\
\hline 28. & Momordica charantia L. & Karela & Cucurbitaceae & Vine & $\begin{array}{l}\text { Whole } \\
\text { Plant }\end{array}$ & $\begin{array}{l}\text { Extract of whole plant and fruit } \\
\text { juice }\end{array}$ \\
\hline 29. & Murraya koeningii (L.) Spreng. & Kari patta & Rutaceae & Tree & Leaf & Leaf juice \\
\hline 30. & Ocimum sanctum L. & Holy Basil & Lamiaceae & Sub-shrub & Leaf & Leaf powder with honey \\
\hline 31. & Punica granatum $\mathrm{L}$. & Pomegranate & Lythraceae & Tree & Fruit & Fruit \\
\hline 32. & Schima wallichiiv (DC.) Korth. & Needlewood Tree & Theaceae & Tree & Leaf & Fresh extract \\
\hline 33. & Scoparia dulcis $\mathrm{L}$. & Goatweed & Plantaginaceae & Herb & Whole plant & Decoction of whole plant \\
\hline 34. & $\begin{array}{l}\text { Sesbania sesban } \\
\text { (Jacq.) W. Wight }\end{array}$ & Jayanti & Fabaceae & Shrub & Leaf & Leaf decoction \\
\hline 35. & Syzygium cumini (L.) Skeels & Jamun & Myrtaceae & Tree & Seed & Dried seed powder \\
\hline 36. & $\begin{array}{l}\text { Terminalia } \\
\text { chebula Retz }\end{array}$ & Hortokhi & Combretaceae & Tree & Seed & Seed powder and decoction \\
\hline 37. & Trigonella foenum- graceum L. & Methi & Leguminosae & Herb & Seed & Filtrate of soaked seeds \\
\hline 38. & Tinospora cordofilia (Willd.) Miers & Giloya & Menispermaceae & Climber & $\begin{array}{l}\text { Whole } \\
\text { Plant }\end{array}$ & Crushed leaf juice \\
\hline 39. & Xanthium indicum Koenig in Roxb. & Burweed & Asteraceae & Herb & Leaf & Vegetable made from young leaves \\
\hline 40. & Zingiber officinale Roscoe & Ginger & Zingiberaceae & Herb & Rhizome & $\begin{array}{l}\text { Small amount of dried powdered } \\
\text { rhizome mixed in curries \& soups, } \\
\text { taken with milk in empty stomach }\end{array}$ \\
\hline
\end{tabular}

property in normal glycemic and streptozotocin induced diabetic rats. Two fractions of ethanolic extract of A. catechu bark comparable to chloroform, petroleum ether, acetone and aqueous extract shows markable anti-hyperglycemic property in alloxan-induced diabetic rats at 2 dose of $200 \mathrm{mg} / \mathrm{kg}$ and $400 \mathrm{mg} / \mathrm{kg}$. The study included various parameters such as glucose, creatinine, low density lipoprotein, high density lipoprotein, urea, serum triglyceride and serum cholesterol ${ }^{56}$.

\section{Aegle marmelos (L.) Correa}

The leaf extract using aqueous solvent shows significant normalization of lipid parameters and blood glucose level at $300 \mathrm{mg} / \mathrm{kg}$ in streptozotocin induced diabetic mice. In vitro, this extract also releases insulin, thus reflects hypoglycemic activity ${ }^{57}$. In non-insulin dependent diabetic patients oral administration of A. marmelos leaves lowers down blood glucose level at a dose of $5 \mathrm{~g} / \mathrm{day}^{58}$. Callus and leaf in methanolic extract reveals antidiabetic property at a dose of $1 \mathrm{~g} / \mathrm{kg}$ in rabbits which were induced diabetic using streptozotocin. This doesn't show any activity in chloroform, benzene and petroleum ether extracts ${ }^{59}$.

\section{Allium sativum $L$.}

Dineshkumar et al. ${ }^{60}$ studied the hypolipidemic and antidiabetic activity in diabetic patients when treated with aqueous extract of A. sativum via oral administration . The treatment of $1 \%$ solution $/ \mathrm{kg}$ of $\mathrm{A}$. sativum in alloxan induced rabbits witnesses anti-hyperglycemic activity ${ }^{61}$. In addition, alcoholic extract administration of A. sativum decreases concentration of Candida albicans in kidney and liver homogenates in infected, normol and experimentally induced (streptozotocin) diabetic rats ${ }^{62} .500 \mathrm{mg} / \mathrm{kg}$ dose of DRF/AY/5001, a herbal formulation of A. sativum shows hypoglycaemic activity in normal, epinephrine induced and alloxan induced hyperglycemic rats ${ }^{63}$.

\section{Aloe vera (L.) Burm.f.}

Leaf gel of A. vera shows a significant increase in liver glycogen and body weight whereas, it decreases normalized serum lipids and urine and blood glucose level ${ }^{64}$. Moreover, an administration of ethanolic extract of Aloe vera gel $(300 \mathrm{mg} / \mathrm{kg})$ for 21 days possess markable antihyperlipidaemic activity in streptozotocin induced diabetic rats ${ }^{65}$. Misawa et al. ${ }^{66}$ isolated phytosterols, cycloartanol and lophenol from Aloe vera leaf gel that reduces sugar level for 44 days in type II diabetic animal model at $25 \mathrm{~g} / \mathrm{kg} /$ day . In addition, oral administration of $A$. vera leaf ( 8 weeks) in mice shows significant reduction of plasma glucose in Type 1 diabetes ${ }^{67}$.

\section{Azadirachta indica Juss.}

Leaf extract administration of A. indica normalizes lipid parameters and blood glucose thus, elicits antidyslipidemic and antihyperglycemic property in streptozotocin induced diabetic rats ${ }^{68,69}$. Atangwho et al. ${ }^{70}$ demonstrated that leaf extract of A. indica in combination with Vernonia amygdalina elevates insulin level thus possesses antihyperglycemic property in diabetic rats . Moreover, polyherbal formulation of A. indica and Momordica charantia leaf $(400 \mathrm{mg} / \mathrm{kg})$ shows remarkable antihyperlipidemic and antidiabetic effect ${ }^{71}$.

\section{Beta vulgaris $L$.}

Oral administration of B. vulgaris extract on alternate days for 1 month showed remarkable antidiabetic action by reducing cholesterol and triglyceride in 4 groups diabetic, control, diabetic + extract and control + extract in streptozotocin induced animals ${ }^{72}$. Mzoughi et al. ${ }^{73}$ evaluated in vitro antioxidant and enzyme inhibitory activities ( $\alpha$-glycosidase and $\alpha$-amylase) in ethanol extract of B. vulgaris leaves, thus revealed prominent role as antihyperglycemic agent.

\section{Brassica juncea (L.) Czern}

Anand et al. ${ }^{74}$ in his study demonstrated that administration of $200 \mathrm{mg} /$ $\mathrm{kg}$ aqueous extract of B. juncea seeds daily for 1 month in streptozotocin induced diabetic rats elicits remarkable antihyperlipidaemic and antidiabetic effect. Administration (for 21 days) of B. juncea extract in combination with metformin treated diabetes mellitus by controlling cholesterol and triglyceride level in body. The study was performed in four groups namely, normal, normal+streptozotocin, streptozotocin+metformin and streptozotocin + B. juncea extract where, the dose of metformin and plant extract was 75 and $450 \mathrm{mg} / \mathrm{kg}$ respectively ${ }^{75}$.

\section{Cajanus cajan (L.) Millsp.}

In alloxan induced diabetic rats the methanolic extract of C. cajan leaves elicits decrease in fasting sugar level at two doses of $400 \mathrm{mg} / \mathrm{kg}$ and $600 \mathrm{mg} / \mathrm{kg}^{76}$. In a study made by Manzo and Vitor, showed significant 
antihyperglycemic activity when normal glycemic mice were fed with ethanolic extract of C. cajan leaves ${ }^{77}$.

\section{Catharanthus roseus (L.) G. Don}

Tiong et al. ${ }^{79}$ in his study isolated four alkaloids from C. roseus leaf extract using dichloromethane solvent that possess ameliorated glucose ingestion in pancreatic beta-TC6 cells of mouse ${ }^{78}$. Moreover, extract of C. roseus elicits antidiabetic potential by reducing serum protein and blood glucose in alloxan induced rats . Methanolic extract of P. granatum leaf and twig in 1:1 possess antidiabetic action in STZ induced diabetic rat ${ }^{80,81}$.

\section{Gymnema sylvestre (Retz.) R.Br.Ex Sm.}

The leaf extract of G. sylvestre act as therapy for type II diabetes as in vitro it stimulates insulin secretion with the help of isolated human islets of langerhans and MIN6 beta-cell line ${ }^{82}$. The administration of aqueous leaf extract $(400-800 \mathrm{mg} / \mathrm{kg})$ of G. sylvestre possesses hypoglycemic and hypolipidemic property in alloxan induced diabetic rats ${ }^{83}$. Wei et $a l .{ }^{84}$ isolated conduritol from stem of G. sylvestre possesses antidiabetic activity by elevating splencia, pancreas, thymus index or retarding the atrophy of splencia, pancreas, thymus of the experimentally induced (alloxan) diabetic rats. Moreover, a novel bioactive compound dihydroxy gymnemic triacetate isolated from acetone extract of G. sylvestre elicits antihyperlipidemic and hypoglycemic effect in streptozotocin induced diabetic rats ${ }^{85}$.

\section{Hemidesmus indicus (L.) R.Br.}

Nandy et al. ${ }^{86}$ in his study stated that oral administration (30days) of ethanolic extract of $\mathrm{H}$. indicus root restored the haemoglobin, blood glucose, protein, plasma insulin level. Also, it restored the detained activities of pancreatic enzymes to normal situation in alloxan induced rats ${ }^{86}$. Studies on $\mathrm{H}$. indicus reported the hypoglycaemic effect of rhizome extract due to various phytocompounds viz. hemidine, hemidesminine, hemidesmin-I and hemidesmin-II. Some other phytconstituents such as sterols, tannins, flavonoids, volatile oils and glycosides have also been reported which contribute in antidiabetic potential ${ }^{87}$.

\section{Hibiscus rosa-sinesis $L$.}

Rehana et al. ${ }^{88}$ in his investigation synthesized a nanoparticle of zinc oxide $(\mathrm{ZnO})$ by using various plant extracts viz. Hibiscus rosa-sinesis, Moringa oleifera, Azadirachta indica, Tamarindus indica and Murraya koenigii. The study screened the $\alpha$-glucosidase and $\alpha$-amylase action of $\mathrm{ZnO}$ nanoparticles that reduced the side effects and toxicity of the drugs used to treat diabetes. Five fractions isolated from the leaf extract of $\mathrm{H}$. rosa-sinensis using ethanol solvent reveals antihyperlipidemic and antidiabetic action in non-obese diabetic mouse ${ }^{89}$. In addition, acute and sub acute treatment of diabetes in alloxan induced diabetic rats, through two doses (250 and $500 \mathrm{mg} / \mathrm{kg}$ ) of ethanol extract of $\mathrm{H}$. rosa-sinensis flowers shows remarkable reduction in blood glucose ${ }^{90}$.

\section{Lantana camara L.}

Administration of methanolic extract (200 and $400 \mathrm{mg} / \mathrm{kg}$ ) of $\mathrm{L}$. camara leaf shows significant antihyperlipidemic and antidiabetic activities by controlling parameters such as low density lipoprotein, high density lipoprotein, total cholesterol and triglycerides ${ }^{91}$. Kumar et al. ${ }^{92}$ studied the antidiabetic effect of ethanolic extract of $\mathrm{L}$. aculeate root in rats injected with alloxan. Moreover, Venkatachalam et al. ${ }^{93}$ studied remarkable antihyperglycemic property of methanolic extract of L. camara fruit on the basis of $\mathrm{HbAlc}$ profile, body weight and histopathological studies of normal and streptozotocin induced diabetic rats.

\section{Mangifera indica $L$.}

The aqueous extract of M. indica stem bark elicits hypoglycemic activity when intraperitonealy administrated $(50-800 \mathrm{mg} / \mathrm{kg})$ in STZ induced diabetic rats ${ }^{94}$. Li et al. ${ }^{95}$ isolated mangiferin, a polyphenol from $\mathrm{M}$. indica plant that prevents diabetic nephropathy progression. They also observed the improvement in renal function of diabetic nephropathy rat model. Furthermore, oral administration of M. indica peel extract at a concentration of $200 \mathrm{mg} / \mathrm{kg}$ elicits remarkable antihyperlipidemic and antidiabetic effect in streptozotocin induced diabetic rats ${ }^{96}$. The study of Wang et al. ${ }^{97}$ demonstrated the role of mangiferin in preventing diabetes induced nephropathy progression in STZ induced diabetic rats. The study also focused on the protection of podocyte through autophagy in glomerulus of diabetic rat ${ }^{97}$.

\section{Momordica charantia L.}

Sathishsekar and Subramanian investigated the role of seed extract of $\mathrm{M}$. charantia in reducing $(150 \mathrm{mg} / \mathrm{kg})$ renal and hepatic thiobarbituric acid reactive substances, hydroperoxides and fasting blood glucose. The study also witnessed a significant reduction in superoxide dismutase, glutathione-s-transferase, catalase, reduced glutathione and glutathione peroxidase in the kidney and liver of diabetic rats ${ }^{98}$. Alcalase hydrolysate, a phytoconstituent from M. charantia possessed higher hypoglycaemic property in comparision to pancreatin hydrolysate ${ }^{99}$. Wang et al. ${ }^{100}$ established a comparable study between Indian and Chinese M. charantia by measuring various parameters such as total triterpene, totat phenol, antidiabetic activity and antioxidant property using reducing power, free radical scavenging, $\alpha$-glucosidase inhibition and $\alpha$-amylase inhibition assays. Furthermore, subcutaneous administration of alcoholic extract and fresh juice of $\mathrm{M}$. charantia fruit causes hypolipidemic, hepato-renal protective and antidiabetic effect in experimentally induced (alloxan) diabetic rats ${ }^{101}$.

\section{Ocimum sanctum $L$.}

Three new phytoconstituents namely, ocimarin, ocimumosides A and ocimumoside, isolated from leaves of $\mathrm{O}$. sanctum revealed anti-stress activity. Out of which, ocimumosides A shows anti-stress property by controlling plasma corticosterone, adrenal hypertrophy, plasma creatine kinase and hyperglycemia ${ }^{102}$. Aerial part extract of O. sanctum using two solvents (chloroform and hydro alcohol) witnessed the antidiabetic effect in alloxan induced diabetic rats at two doses of 250 and $500 \mathrm{mg} / \mathrm{kg}{ }^{103,104}$. Furthermore, triterpenoid which was isolated from aerial part extract (Hydro alcoholic) of O. sanctum at $20 \mathrm{mg} / \mathrm{kg}$ dose shows antidiabetic effect in alloxan induced diabetic rats ${ }^{105}$.

\section{Punica granatum L.}

Huang et al. ${ }^{106}$ reported that, oral administration of flower extract of P. granatum reduces glucose loading induced ameliorates level of plasma glucose in Zucker diabetic fatty rats at $500 \mathrm{mg} / \mathrm{kg} .200 \mathrm{mg} / \mathrm{kg}$ dose of P. granatum fruit peel extract controls all the adverse effects thus possesses anti-peroxidative and antidiabetic potential in alloxan mice ${ }^{92}$. Moreover, oral administration of P. granatum flower extract using aqueous solvent elevates oxidative stresses, lipid parameters and blood glucose in STZ induced diabetic rats ${ }^{107}$. In addition, McFarlin et al. ${ }^{108}$ administrated the seed oil of P. granatum that reduced the lipid parameters and blood glucose in mice.

\section{Scoparia dulcis $L$.}

Pamunuwa et al. ${ }^{109}$ investigated the antidiabetic effect of S. dulcis through curbing of PPAR- $\gamma$, ameliorated insulin secretion and $\alpha$-glucosidase inhibition. The study reported the presence of various compounds viz. scutellarein, luteolin, glutinol, coixol, apigenin, scoparic acid A and scoparic acid D responsible for antidiabetic potential. Scoparic 
acid D, (diterpenoid) isolated from S. dulcis ethanol extract reflects antihyperglycaemic activity by normalizing level of plasma insulin in STZ induced diabetic Wistar rats at 10, 20 and $40 \mathrm{mg} / \mathrm{kg}$ for 15 days ${ }^{110}$. Furthermore, oral administration of S. dulcis plant extract shows remarkable hypoglycemic activity when orally administrated (100 and $200 \mathrm{mg} \mathrm{kg}^{-1}$ ) in alloxan induced diabetic mice. The study presented a comparative analysis between plant extract and metformin treatment of diabetes ${ }^{111}$

\section{Tinospora cordifolia (Willd.) Miers}

Patel et al. demonstrated the antidiabetic potential of T. cordifolia stem extract using various solvents viz. methanol, ethyl acetate and hexane, by decreasing blood sugar in STZ induced diabetic rats at $250 \mathrm{mg}$ $\mathrm{kg}^{-1112}$. Dihar, a polyherbal formulation consisting of eight plants viz. Gymnema sylvestre, Momordica charantia, Syzygium cumini, Emblica officinalis, Curcuma longa, Azadirachta indica, Enicostemma littorale and $\mathrm{T}$. cordifolia remarkably decreases lipid peroxidation level and ameliorates activity of antioxidant enzymes in STZ induced diabetic rats $^{113}$. T. cordifolia stem extract using chloroform, dichloromethane, ethyl acetate and hexane solvents were analysed for a-glucosidase inhibition action which resulted that only dichloromethane extract have $100 \%$ a-glucosidase inhibition ${ }^{114}$. In addition, saponarin isolated from T. cordifolia leaf extract elicits hypoglycemic effect at $20-80 \mathrm{mg}$ $\mathrm{kg}^{-1}$ dose ${ }^{115}$

\section{Trigonella foenum-graecum $L$.}

Oral administration of $\mathrm{T}$. foenum-graecum ethanol extract reflects antidiabetic property at dose of $0.1,0.25$ and $0.5 \mathrm{~g} / \mathrm{kg}$ in STZ induced diabetic rats by controlling triacylglycerol, creatinine, serum glucose, uric acid, urea, total cholesterol, alanine aminotransferase and aspartate aminotransferase ${ }^{116}$. Losso et al. reported that intake of $\mathrm{T}$. foenumgraecum seeds (5\%) incorporated in bread in a diet controlled diabetic subject elicits significant reduction in blood glucose ${ }^{117}$. In addition, oral administration ( 4 or $8 \mathrm{~g}$ ) of fiber yielded from $\mathrm{T}$. foenum-graecum to healthy obese subjects results in enhanced satiety and reduced energy ingestion ${ }^{118}$. T. foenum-graecum seed extract using ethanol solvent shows dose dependent hypoglycemic property relative to oral antidiabetic drugs in alloxan induced diabetic rats at 2, 1, 0.5 and $0.1 \mathrm{~g} / \mathrm{kg}$ doses ${ }^{119-121}$. Furthermore, 4-hydroxyisoleucine, an amino acid extracted from $\mathrm{T}$. foenum-graecum possesses antidiabetic and insulinotropic properties by controlling glucose level or liver damage in STZ induced rats ${ }^{122}$.

\section{CONCLUSION}

In traditional medical system, a number of medicinal plants have been recorded which have offered a promising line for the treatment of diabetes mellitus. Many of them have been explored and scientifically validated. However, for the majority of plant species, there is still a need of reverse pharmacology to validate their efficacy and potential. Some of the plants such as, Syzygium cumini, Aegle marmelos, Aloe vera, Azadiracta indica, Zingiber officinale, Murraya koeningii, Gymnema sylvestre, Momordica charantia and Allium sativum have witnessed their varying level of hypoglycemic activity. In addition, these plants have also found effective in controlling the complications of diabetes. Further, more studies may be targeted in isolation, identification and characterization of bioactive constituents of medicinal plants. The outcomes of current study may serve as an initiation point for potential antidiabetic drug development. This review may help in reverse pharmacology and development of safe therapeutic drugs for the treatment of diabetes, a devastating disease.

\section{REFERENCES}

1. Keter LK, Mutiso PC. Ethnobotanical studies of medicinal plants used by Traditional Health Practitioners in the management of diabetes in Lower Eastern Province, Kenya. Journal of Ethnopharmacology. 2012 Jan 6;139(1):74-80
2. Athyros VG, Imprialos K, Stavropoulos K, Sahinidis A, Doumas M. Understanding the cardiovascular risk with non-insulin antidiabetic drugs. Expert opinion on drug safety. 2019 Mar 4;18(3):241-51.

3. WHO (2019). fact-sheets/detail/diabetes. 11/3/2020).

https://www.who.int/news-room/ (Accessed

4. Dixit S, Tiwari S. Investigation of anti-diabetic plants used among the ethnic communities of Kanpur division, India. Journal of Ethnopharmacology. 2020 May 10;253:112639.

5. Nagarathna R, Tyagi R, Battu P, Singh A, Anand A, Nagendra HR. Assessment of risk of diabetes by using Indian Diabetic risk score (IDRS) in Indian population. Diabetes Research and Clinical Practice. 2020 Apr 1;162:108088.

6. Chen L, Magliano DJ, Zimmet PZ. The worldwide epidemiology of type 2 diabetes mellitus-present and future perspectives. Nature reviews endocrinology. 2012 Apr;8(4):228-36.

7. Rizvi SI, Mishra N. Traditional Indian medicines used for the management of diabetes mellitus. Journal of diabetes research. 2013;2013.

8. Ali MK, Narayan KV, Tandon N. Diabetes \& coronary heart disease: current perspectives. The Indian journal of medical research. 2010 Nov;132(5):584

9. Banerji MA, Faridi N, Atluri R, Chaiken RL, Lebovitz HE. Body composition, visceral fat, leptin, and insulin resistance in Asian Indian men. The journal of clinical endocrinology \& metabolism. 1999 Jan 1;84(1):137-44.

10. Dudeja V, Misra A, Pandey RM, Devina G, Kumar G, Vikram NK. BMI does not accurately predict overweight in Asian Indians in northern India. British journa of nutrition. $2001 \mathrm{Jul} ; 86(1): 105-12$

11. Neamsuvan $O$, Madeebing $N$, Mah L, Lateh W. A survey of medicinal plants for diabetes treating from Chana and Nathawee district, Songkhla province, Thailand. Journal of ethnopharmacology. 2015 Nov 4;174:82-90.

12. Shafrir E. Development and consequences of insulin resistance: lessons from animals with hyperinsulinaemia. Diabetes \& metabolism. 1996 Apr;22(2):122 31.

13. Sashikanth YV, Aravindkumar P, Swarupa C. Two way relation of diabetes mellitus and periodontitis—a review. Annals and Essences of Dentistry. 2012;4(1):35-8.

14. Sani UM. Phytochemical screening and antidiabetic effect of extracts of the seeds of Citrullus lanatus in alloxan-induced diabetic albino mice. Journal of Applied Pharmaceutical Science. 2015 Mar;5(3):51-4.

15. Mehta SR, Kashyap AS, Das S. Diabetes mellitus in India:The modern scourge. Medical journal armed forces India. 2009 Jan 1;65(1):50-4.

16. Verma S, Gupta M, Popli H, Aggarwal G. Diabetes mellitus treatment using herbal drugs. International Journal of Phytomedicine. 2018;10(1):1-0.

17. Moses RG. Combination therapy for patients with Type 2 diabetes: repaglinide in combination with metformin. Expert review of endocrinology \& metabolism. 2010 May 1;5(3):331-42.

18. Chaudhury A, Duvoor C, Dendi R, Sena V, Kraleti S, Chada A, Ravilla R, Marco A, Shekhawat NS, Montales MT, Kuriakose K. Clinical review of antidiabetic drugs: implications for type 2 diabetes mellitus management. Frontiers in endocrinology. 2017 Jan 24;8:6.

19. Flekač M, Šoupal J. Clinical efficacy and safety of basal insulin analogue glargine in patients with type 2 diabetes mellitus. Vnitrni lekarstvi. 2016;62(9):705-11.

20. Dowarah J, Singh VP. Anti-diabetic drugs recent approaches and advancements. Bioorganic \& Medicinal Chemistry. 2020 Jan 8:115263.

21. Krentz AJ, Bailey CJ. Oral antidiabetic agents. Drugs. 2005 Feb 1;65(3):385-411.

22. Scheen AJ, Lefèbvre PJ. Oral antidiabetic agents. Drugs. 1998 Feb 1;55(2):22536.

23. Dalama B, Mesa J. New oral hypoglycemic agents and cardiovascular risk Crossing the metabolic border. Revista Española de Cardiología (English Edition). 2016 Nov 1;69(11):1088-97.

24. Gupta V. Glucagon-like peptide-1 analogues: an overview. Indian journal of endocrinology and metabolism. 2013 May;17(3):413.

25. Yaribeygi H, Simental-Mendía LE, Barreto GE, Sahebkar A. Metabolic effects of antidiabetic drugs on adipocytes and adipokine expression. Journal of cellular physiology. 2019 Oct;234(10):16987-97.

26. Levetan C. Oral antidiabetic agents in type 2 diabetes. Current medical research and opinion. 2007 Apr 1;23(4):945-52.

27. Niazi AK, Niazi SH. A novel strategy for the treatment of diabetes mellitussodium glucose co-transport inhibitors. North American journal of medical sciences. 2010 Dec;2(12):556

28. Gallwitz B. Glucagon-like peptide-1 analogues for type 2 diabetes mellitus Drugs. 2011 Sep 1;71(13):1675-88.

29. Kyriacou A, Ahmed AB. Exenatide use in the management of type 2 diabetes mellitus. Pharmaceuticals. 2010 Aug;3(8):2554-67.

30. Shweta Singh RK, Kumar R, Pal R, Kumar N, Dixit RK, Nath R. Switch Over to Alternative Therapy for Diabetes Mellitus â€"A Life Style Disease. Current Research in Diabetes \& Obesity Journal. 2016;1(2):1-8. 
31. Wadkar KA, Magdum CS, Patil SS, Naikwade NS. Antidiabetic potential and Indian medicinal plants. Journal of herbal medicine and toxicology. 2008;2(1):4550.

32. Rasouli H, Yarani R, Pociot F, Popović-Djordjević J. Anti-diabetic potential of plant alkaloids: Revisiting current findings and future perspectives. Pharmacological Research. 2020 Feb 24:104723.

33. Ahmed MA, Muntingh G, Rheeder P. Vitamin B12 deficiency in metformintreated type-2 diabetes patients, prevalence and association with peripheral neuropathy. BMC Pharmacology and Toxicology. 2016 Dec;17(1):44.

34. KALSI A, SINGH S, TANEJA N, KUKAL S, MANI S. Current treatments for Type 2 diabetes, their side effects and possible complementary treatments. International Journal. 2017;10:3

35. Linhart A, Bělohlávek J. Type 2 diabetes mellitus and heart failure. Vnitrni lekarstvi. 2016;62(7-8):592-7.

36. Farag M, Ahmed WJ, Foud I, Mohammed MS. The role of medicinal plants in the treatment of type-2 diabetes. Adv J Pharm Life Sci Res. 2014;4:1-8.

37. Gao X, Cai X, Yang W, Chen Y, Han X, Ji L. Meta-analysis and critical review on the efficacy and safety of alpha-glucosidase inhibitors in Asian and non-Asian populations. Journal of diabetes investigation. $2018 \mathrm{Mar} ; 9(2): 321-31$.

38. Sanchez-Rangel E, Inzucchi SE. Metformin: clinical use in type 2 diabetes. Diabetologia. 2017 Sep 1;60(9):1586-93

39. Davies MJ, D'Alessio DA, Fradkin J, Kernan WN, Mathieu C, Mingrone G, Rossing P, Tsapas A, Wexler DJ, Buse JB. Management of hyperglycemia in type 2 diabetes, 2018. A consensus report by the American Diabetes Association (ADA) and the European Association for the Study of Diabetes (EASD). Diabetes care. 2018 Dec 1;41(12):2669-701.

40. Consoli A, Formoso G. Potential side effects to GLP-1 agonists: understanding their safety and tolerability. Expert opinion on drug safety. 2015 Feb 1;14(2):20718.

41. Geneva WH. Traditional medicine-growing needs and potential. WHO Policy Perspectives Med. 2002; 2: 1. 2002;6.

42. Rani V, Gupta A, Awasthi S, Suneja T, Yadav M, Verma S. Antidiabetic Activity of Indian Medicinal Plants. InHerbal Medicine in India 2020 (pp. 155-174). Springer, Singapore.

43. Modak M, Dixit P, Londhe J, Ghaskadbi S, Devasagayam TP. Recent advances in Indian herbal drug research guest editor: Thomas Paul Asir Devasagayam Indian herbs and herbal drugs used for the treatment of diabetes. Journal of clinical biochemistry and nutrition. 2007;40(3):163-73.

44. Patil R, Patil R, Ahirwar B, Ahirwar D. Current status of Indian medicinal plants with antidiabetic potential: a review. Asian Pacific Journal of Tropical Biomedicine. 2011 Oct 1;1(2):S291-8.

45. Yatoo MI, Saxena A, Gopalakrishnan A, Alagawany M, Dhama K. Promising antidiabetic drugs, medicinal plants and herbs: An update. International Journal of Pharmacology. 2017 Jan 1;13(7):732-45.

46. Liu J, Shi YC, Lee DY. Applications of Pueraria lobata in treating diabetics and reducing alcohol drinking. Chinese Herbal Medicines. 2019 Apr 5.

47. Malla B, Gauchan DP, Chhetri RB. An ethnobotanical study of medicinal plants used by ethnic people in Parbat district of western Nepal. Journal of ethnopharmacology. 2015 May 13;165:103-17.

48. Goyal M. Traditional plants used for the treatment of diabetes mellitus in Sursagar constituency, Jodhpur, Rajasthan-An ethnomedicinal survey. Journal of ethnopharmacology. 2015 Nov 4;174:364-8.

49. Sheikh Y, Maibam BC, Biswas D, Laisharm S, Deb L, Talukdar NC, Borah JC. Anti-diabetic potential of selected ethno-medicinal plants of north east India. Journal of ethnopharmacology. 2015 Aug 2;171:37-41

50. Tarafdar RG, Nath S, Talukdar AD, Choudhury MD. Antidiabetic plants used among the ethnic communities of Unakoti district of Tripura, India. Journal of ethnopharmacology. 2015 Feb 3;160:219-26.

51. ljaz F, labal Z, Rahman IU, Alam J, Khan SM, Shah GM, Khan K, Afzal A. Investigation of traditional medicinal floral knowledge of Sarban Hills, Abbottabad, KP, Pakistan. Journal of ethnopharmacology. 2016 Feb 17;179:20833.

52. Chinsembu KC. Diabetes mellitus and nature's pharmacy of putative antidiabetic plants. Journal of Herbal Medicine. 2019 Mar 1;15:100230.

53. Chakraborty R, De B, Devanna N, Sen S. North-East India an ethnic storehouse of unexplored medicinal plants. J Nat Prod Plant Resour. 2012;2(1):143-52.

54. Upadhyay B, Roy S, Kumar A. Traditional uses of medicinal plants among the rural communities of Churu district in the Thar Desert, India. Journal of ethnopharmacology. 2007 Sep 25;113(3):387-99.

55. Bhatia V, Srivastava SP, Srivastava R, Mishra A, NarenderT, Maurya R, Srivastava AK. Antihyperglycaemic and aldose reductase inhibitory potential of Acacia catechu hard wood and Tectona grandis leaves. Medicinal Chemistry Research. 2011 Dec 1;20(9):1724-31
56. Jarald E, Joshi SB, Jain DC. Biochemical study on the hypoglycaemic effects of extract and fraction of Acacia catechu willd in alloxan-induced diabetic rats. Int J Diabetes \& Metabolism. 2009;17:63-9.

57. Sharma B, Satapathi SK, Roy P. Hypoglycemic and hypolipidemic effect of Aegle marmelos (L.) leaf extract on streptozotocin induced diabetic mice. Int $J$ Pharmacol. 2007;3(6):144-52.

58. Ismail MY, Yaheya M. Clinical evaluation of antidiabetic activity of Trigonella seeds and Aegle marmelos leaves. World Applied Sciences Journal. 2009;7(10):1231-4.

59. Arumugam S, Kavimani S, Kadalmani B, Ahmed AB, Akbarsha MA, Rao MV Antidiabetic activity of leaf and callus extracts of Aegle marmelos in rabbit.

60. Dineshkumar B, Analava M, Manjunatha M. Antidiabetic and hypolipidaemic effects of few common plants extract in type 2 diabetic patients at Bengal. International Journal of Diabetes and Metabolism. 2010;18(2):59-65.

61. Mahesar H, Bhutto MA, Khand AA, Narejo NT. Garlic used as an alternative medicine to control diabetic mellitus in alloxan-induced male rabbits. Pakistan Journal of Physiology. 2010 Jun 30;6(1):39-41.

62. Bokaeian M, Nakhaee A, Moodi B, Farhangi A, Akbarzadeh A. Effects of garlic extract treatment in normal and streptozotocin diabetic rats infected with Candida albicans. Indian Journal of clinical biochemistry. 2010 Apr 1;25(2):182-7.

63. Mahesar H, Bhutto MA, Khand AA, Narejo NT. Garlic used as an alternative medicine to control diabetic mellitus in alloxan-induced male rabbits. Pakistan Journal of Physiology. 2010 Jun 30;6(1):39-41.

64. Rajendran A, Narayanan V, Gnananvel I. Evaluation of therapeutic efficacy of Aloe vera sap in diabetes and treating wounds and inflammation in animals. $J$ Appl Sci Res. 2007;3(11):1434-6.

65. Rajasekaran S, Ravi K, Sivagnanam K, Subramanian S. Beneficial effects of Aloe vera leaf gel extract on lipid profile status in rats with streptozotocin diabetes. Clinical and Experimental Pharmacology and Physiology. 2006 Mar;33(3):232-7.

66. Misawa E, Tanaka M, Nomaguchi K, Yamada M, Toida T, Takase M, Iwatsuki K, Kawada T. Administration of phytosterols isolated from Aloe vera gel reduce visceral fat mass and improve hyperglycemia in Zucker diabetic fatty (ZDF) rats. Obesity research \& clinical practice. 2008 Dec 1;2(4):239-45.

67. Kim K, Kim H, Kwon J, Lee S, Kong H, Im SA, Lee YH, Lee YR, Oh ST, Jo TH, Park YI. Hypoglycemic and hypolipidemic effects of processed Aloe vera ge in a mouse model of non-insulin-dependent diabetes mellitus. Phytomedicine. 2009 Sep 1;16(9):856-63

68. Bisht S, Sisodia SS. Anti-hyperglycemic and antidyslipidemic potential of Azadirachta indica leaf extract in STZ-induced diabetes mellitus. Journal of Pharmaceutical Sciences and Research. 2010 Oct 1;2(10):622.

69. Chattopadhyay RR, Bandyopadhyay M. Effect of Azadirachta indica leaf extract on serum lipid profile changes in normal and streptozotocin induced diabetic rats. African Journal of Biomedical Research. 2005;8(2):101-4.

70. Atangwho IJ, Ebong PE, Eyong EU, Egbung GE. Combined extracts of Vernonia amygdalina and Azadirachta indica may substitute insulin requirement in the management of type I diabetes. Research Journal of Medicine and Medical Sciences. 2010;5(1):35-9

71. Ebong PE, Atangwho IJ, Eyong EU, Egbung GE. The antidiabetic efficacy of combined extracts from two continental plants: Azadirachta indica (A. Juss) (Neem) and Vernonia amygdalina (Del.)(African bitter leaf). American journal of Biochemistry and Biotechnology. 2008;4(3):239-44

72. Khalili M, Vaez Mahdavi MR. Effect of Beta vulgaris extract on triglyceride and cholesterol in diabetic male rats. Iranian Journal of Pharmaceutical Research. 2010 Nov 20:55-

73. Mzoughi Z, Chahdoura H, Chakroun Y, Cámara M, Fernández-Ruiz V, Morales P. Mosbah H, Flamini G, Snoussi M, Majdoub H. Wild edible Swiss chard leaves (Beta vulgaris L. var. cicla): Nutritional, phytochemical composition and biological activities. Food Research International. 2019 May 1;119:612-21.

74. Anand P, Murali KY, Tandon V, Chandra R, Murthy PS. Preliminary studies on antihyperglycemic effect of aqueous extract of Brassica nigra (L.) Koch in streptozotocin induced diabetic rats.

75. Kumar A, Rana AK, Singh A, Singh A. Bioactivity of methanolic extract of Brassica juncea in animal model of diabetes mellitus. Chinese Herbal Medicines. 2019 Oct 1;11(4):434-7.

76. Ezike AC, Akah PA, Okoli CC, Okpala CB. Experimental evidence for the antidiabetic activity of Cajanus cajan leaves in rats. Journal of basic and clinical pharmacy. 2010 Mar;1(2):81.

77. Manzo JA, Vitor II RJ. Antihyperglycemic effects of Cajanus cajan L. (pigeon pea) ethanolic extract on the blood glucose levels of ICR mice (Mus musculus I.). National Journal of Physiology, Pharmacy and Pharmacology. 2017;7(8):860

78. Tiong SH, Looi CY, Hazni H, Arya A, Paydar M, Wong WF, Cheah SC, Mustafa $\mathrm{MR}$, Awang K. Antidiabetic and antioxidant properties of alkaloids from Catharanthus roseus (L.) G. Don. Molecules. 2013 Aug;18(8):9770-84. 
79. Aruljothi B, Samipillai SS. Antidiabetic activity of Catharanthus roseus in alloxan induced diabetic rats. Int J Modn Res Revs. 2016 Jan;4(3):1121-4.

80. Tolambiya P, Mathur S. A study on potential phytopharmaceuticals assets in Catharanthus roseus L.(Alba). Int J Life Sci Biotechnol Pharm Res. 2016 Jun;5(1):1-6.

81. Singh SN, Vats P, Suri S, Shyam R, Kumria MM, Ranganathan S, Sridharan K. Effect of an antidiabetic extract of Catharanthus roseus on enzymic activities in streptozotocin induced diabetic rats. Journal of Ethnopharmacology. 2001 Aug 1;76(3):269-77.

82. 77oldLiu B, Asare-Anane H, Al-Romaiyan A, Huang G, Amiel SA, Jones PM, Persaud SJ. Characterisation of the insulinotropic activity of an aqueous extract of Gymnema sylvestre in mouse $\beta$-cells and human islets of Langerhans. Cellular Physiology and Biochemistry. 2009;23(1-3):125-32.

83. Mall GK, Mishra PK, Prakash V. Antidiabetic and hypolipidemic activity of Gymnema sylvestre in alloxan induced diabetic rats. Global Journal of Biotechnology and Biochemistry. 2009;4(1):37-42.

84. Wei JH, Zhen HS, Qiu Q, Chen J, Zhou F. [Experimental [corrected] study of hypoglycemic activity of conduritol A of stems of Gymnema sylvestre]. Zhongguo Zhong yao za zhi= Zhongguo zhongyao zazhi= China journal of Chinese materia medica. 2008 Dec;33(24):2961-5.

85. Daisy P, Eliza J, Farook KA. A novel dihydroxy gymnemic triacetate isolated from Gymnema sylvestre possessing normoglycemic and hypolipidemic activity on STZ-induced diabetic rats. Journal of ethnopharmacology. 2009 Nov 12;126(2):339-44

86. Nandy S, Mukheriee A, Pandey DK, Ray P, Dey A. Indian Sarsaparilla (Hemidesmus indicus): Recent progress in research on ethnobotany, phytochemistry and pharmacology. Journal of Ethnopharmacology. 2020 May 23;254:112609

87. Mazumder A, Das S. STUDY OF ORAL HYPOGLYCEMIC ACTIVITY OF RHIZOMES OF HEMIDESMUS INDICUS R. Br. IN ALBINO WISTAR RATS. International Journal of Pharmaceutical Sciences and Research. 2016 Nov 1;7(11):4602

88. Rehana D, Mahendiran D, Kumar RS, Rahiman AK. In vitro antioxidant and antidiabetic activities of zinc oxide nanoparticles synthesized using different plant extracts. Bioprocess and biosystems engineering. 2017 Jun 1;40(6):94357.

89. Mogbel FS, Naik PR, Najma HM, Selvaraj S. Antidiabetic properties of Hibiscus rosa sinensis $L$. leaf extract fractions on non-obese diabetic (NOD) mouse.

90. Venkatesh S, Thilagavathi J. Anti-diabetic activity of flowers of Hibiscus rosasinensis. Fitoterapia. 2008 Feb 1;79(2):79-81.

91. Ganesh T, Sen S, Thilagam E, Thamotharan G, Loganathan T, Chakraborty R. Pharmacognostic and anti-hyperglycemic evaluation of Lantana camara (L.) var. aculeate leaves in alloxan-induced hyperglycemic rats. International Journal of Research in Pharmaceutical Sciences. 2010 Jul 25;1(3):247-52

92. Kumar KV, Sharief SD, Rajkumar R, llango B, Sukumar E. Antidiabetic potential of Lantana aculeata root extract in alloxan-induced diabetic rats. International Journal of Phytomedicine. 2010 Jul 1;2(3).

93. Venkatachalam T, Kumar VK, Selvi PK, Maske AO, Anbarasan V, Kumar PS Antidiabetic activity of Lantana camara Linn fruits in normal and streptozotocininduced diabetic rats. J Pharm Res. 2011 May:4(5):1550-2.

94. Ojewole JA. Antiinflammatory, analgesic and hypoglycemic effects of Mangifera indica Linn. (Anacardiaceae) stem-bark aqueous extract. Methods and findings in experimental and clinical pharmacology. 2005 Oct 1;27(8):547-54.

95. Li X, Cui X, Sun X, Li X, Zhu Q, LiW. Mangiferin prevents diabetic nephropathy progression in streptozotocin-induced diabetic rats. Phytotherapy Research. 2010 Jun;24(6):893-9.

96. Parmar HS, Kar A. Possible amelioration of atherogenic diet induced dyslipidemia, hypothyroidism and hyperglycemia by the peel extracts of Mangifera indica, Cucumis melo and Citrullus vulgaris fruits in rats. Biofactors. 2008:33(1):13-24

97. Wang X, Gao L, Lin H, Song J, Wang J, Yin Y, Zhao J, Xu X, Li Z, Li L. Mangiferin prevents diabetic nephropathy progression and protects podocyte function via autophagy in diabetic rat glomeruli. European journal of pharmacology. 2018 Apr 5;824:170-8

98. Sathishsekar D, Subramanian S. Antioxidant properties of Momordica Charantia (bitter gourd) seeds on Streptozotocin induced diabetic rats. Asia Pacific journa of clinical nutrition. 2005 Jun 1;14(2):153.

99. Yuan X, Gu X, Tang J. Optimization of the production of Momordica charantia L. Var. abbreviata Ser. protein hydrolysates with hypoglycemic effect using Alcalase. Food chemistry. 2008 Nov 15;111(2):340-4.

100. Wang L, Clardy A, Hui D, Gao A, WuY. Antioxidant and antidiabetic properties of Chinese and Indian bitter melons (Momordica charantia L.). Food Bioscience. 2019 Jun 1;29:73-80.

101. El Batran SA, El-Gengaihi SE, El Shabrawy OA. Some toxicological studies of Momordica charantia L. on albino rats in normal and alloxan diabetic rats. Journal of ethnopharmacology. 2006 Nov 24;108(2):236-42.
102. Gupta P, Yadav DK, Siripurapu KB, Palit G, Maurya R. Constituents of Ocimum sanctum with antistress activity. Journal of natural products. 2007 Sep 28;70(9):1410-6.

103. Patil RN, Patil RY, Ahirwar D. Study of some medicinal plants for antidiabetic activity in alloxan induced diabetes. Pharmacologyonline. 2010;1 (1):53-60.

104. Patil RN, Patil RY, Ahirwar B, Ahirwar D. Evaluation of antidiabetic and related actions of some Indian medicinal plants in diabetic rats. Asian Pacific Journal of Tropical Medicine. 2011 Jan 1;4(1):20-3.

105. Patil R, Patil R, Ahirwar B, Ahirwar D. Isolation and characterization of anti-diabetic component (bioactivity-guided fractionation) from Ocimum sanctum L.(Lamiaceae) aerial part. Asian Pacific journal of tropical medicine. 2011 Apr 1;4(4):278-82.

106. Huang TH, Peng G, Kota BP, Li GQ, Yamahara J, Roufogalis BD, Li Y. Antidiabetic action of Punica granatum flower extract: activation of PPAR- $\gamma$ and identification of an active component. Toxicology and applied pharmacology. 2005 Sep 1;207(2):160-9.

107. Bagri P, Ali M, Aeri V, Bhowmik M, Sultana S. Antidiabetic effect of Punica granatum flowers: effect on hyperlipidemia, pancreatic cells lipid peroxidation and antioxidant enzymes in experimental diabetes. Food and Chemical Toxicology. 2009 Jan 1;47(1):50-4.

108. McFarlin BK, Strohacker KA, Kueht ML. Pomegranate seed oil consumption during a period of high-fat feeding reduces weight gain and reduces type 2 diabetes risk in CD-1 mice. British Journal of Nutrition. 2008 Dec;102(1):54-9.

109. Pamunuwa G, Karunaratne D, Waisundara VY. Antidiabetic Properties, bioactive constituents, and other therapeutic effects of scoparia dulcis. Evidence-Based Complementary and Alternative Medicine. 2016;2016.

110. Latha M, Pari L, Ramkumar KM, Rajaguru P, Suresh T, Dhanabal T, Sitasawad $\mathrm{S}$, Bhonde R. Antidiabetic effects of scoparic acid D isolated from Scoparia dulcis in rats with streptozotocin-induced diabetes. Natural Product Research. 2009 Nov 10;23(16): 1528-40.

111. Zulfiker AH, Ripa FA, Rahman MM, Ullah MO, Hamid K, Khan MM, Rana MS Antidiabetic and antioxidant effect of Scoparia dulcis in alloxan induced albino mice. International Journal of PharmTech Research. 2010 Jan 1;2(4):2527-34.

112. Rajalakshmi M, Eliza J, Priya CE, Nirmala A, Daisy P. Anti-diabetic properties of Tinospora cordifolia stem extracts on streptozotocin-induced diabetic rats. Afr J Pharm Pharmacol. 2009 May 1;3(5):171-80.

113. Patel SS, Shah RS, Goyal RK. Antihyperglycemic, antihyperlipidemic and antioxidant effects of Dihar, a polyherbal ayurvedic formulation in streptozotocin induced diabetic rats.

114. Chougale AD, Ghadyale VA, Panaskar SN, Arvindekar AU. Alpha glucosidase inhibition by stem extract of Tinospora cordifolia. Journal of Enzyme Inhibition and Medicinal Chemistry. 2009 Aug 1;24(4):998-1001.

115. Sengupta S, Mukherjee A, Goswami R, Basu S. Hypoglycemic activity of the antioxidant saponarin, characterized as $\alpha$-glucosidase inhibitor present in Tinospora cordifolia. Journal of enzyme inhibition and medicinal chemistry. 2009 Jun 1;24(3):684-90

116. Eidi A, Eidi M, Sokhteh M. Effect of fenugreek (Trigonella foenum-graecum L) seeds on serum parameters in normal and streptozotocin-induced diabetic rats. Nutrition Research. 2007 Nov 1;27(11):728-33.

117. Losso JN, Holliday DL, Finley JW, Martin RJ, Rood JC, Yu Y, Greenway FL. Fenugreek bread: a treatment for diabetes mellitus. Journal of medicinal food. 2009 Oct 1;12(5):1046-9.

118. Mowl A, Alauddin M, Rahman M, Ahmed K. Antihyperglycemic effect of Trigonella foenum-graecum (Fenugreek) seed extract in alloxan-induced diabetic rats and its use in diabetes mellitus: a brief qualitative phytochemical and acute toxicity test on the extract. African Journal of Traditional, Complementary and Alternative Medicines. 2009;6(3).

119. Tewari $V$, Tewari A, Bhardwaj N. Histological and histochemical changes in placenta of diabetic pregnant females and its comparision with normal placenta. Asian Pacific Journal of Tropical Disease. 2011 Mar 1:1(1):1-4.

120. Arjunan I, Gopinath D, Murthy NS. Role of informal care providers in home based long term care in diabetes mellitus at Kaiwara Primary Health Center area, Karnataka, India. Asian Pacific Journal of Tropical Disease. 2011 Jun 1:1(2):127-30.

121. Idogun ES, Kasia BE. Assessment of microalbuminuria and glycated hemoglobin in type 2 diabetes mellitus complications. Asian Pacific Journal of Tropical Disease. 2011 Sep 1;1(3):203-5.

122. Haeri MR, Izaddoost M, Ardekani MR, Nobar MR, White KN. The effect of fenugreek 4-hydroxyisoleucine on liver function biomarkers and glucose in diabetic and fructose-fed rats. Phytotherapy Research: An International Journal Devoted to Pharmacological and Toxicological Evaluation of Natural Product Derivatives. 2009 Jan;23(1):61-4. 


\section{GRAPHICAL ABSTRACT}

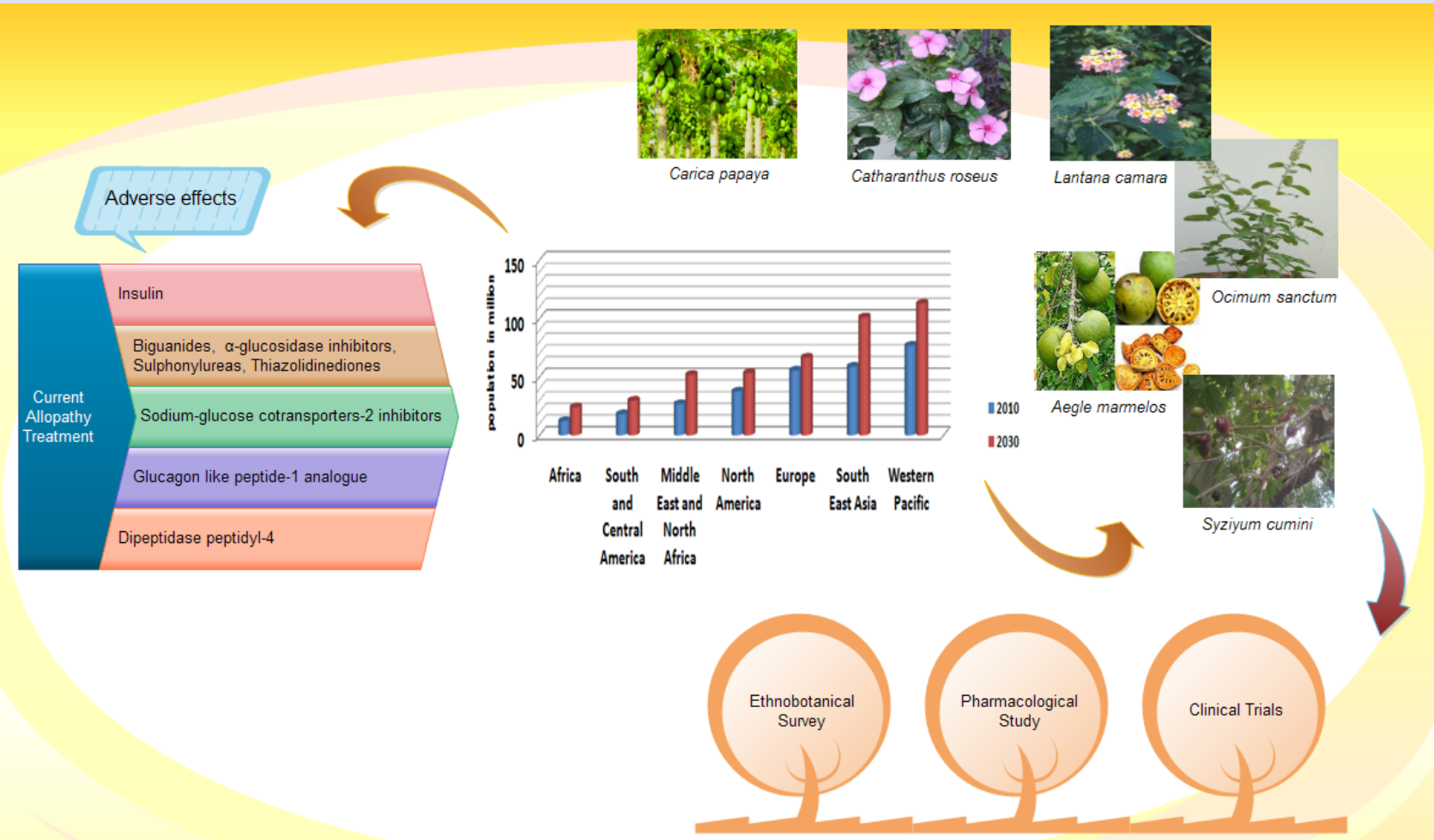

\section{ABOUT AUTHORS}

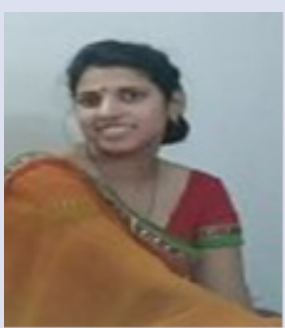

Shikha Dixit is a research scholar in the department of Botany, Chhatrapati Shahu Ji Maharaj University (CSJMU) Kanpur, India. She is an active researcher in the field of herbal medicine and ethno-pharmacology. She has published a number of research articles in the field of herbal medicine and anti-diabetic plants. She is active reviewer of many reputed journals.

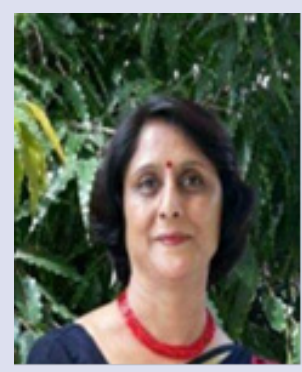

Sugandha Tiwari received her PhD from CSJMU Kanpur. She is currently an associate professor in the department of botany CSJMU Kanpur. She has published a number of research articles in the field of anti-diabetic plants, and ethno-pharmacology. She is also active reviewer of many reputed journals. Her research interest includes plant science, herbal medicine and pharmacology.

Cite this article: Dixit S, Tiwari S. Review on Plants for Management of Diabetes in India: An Ethno-Botanical and Pharmacological Perspective. Pharmacogn J. 2020;12(6)Suppl:1801-10. 